\title{
SALLAI JÁNOS: AZ ÁLLAMHATÁROK
}

\author{
(Press Publica Kiadó, Budapest, 2004. 128 o.)
}

\section{BARANYI BÉLA}

Jó másfél-két évtizede már, hogy az egységesülő Európában az európai regionális politikák, akárcsak a területi tudományok figyelme egyre élénkülö érdeklődéssel fordult a politikai államhatárok, a határmentiség és a határon átnyúló együttmüködés kérdéseinek a tanulmányozása irányába. Több mint nyilvánvaló, hogy a határmentiség kérdése, a politikai államhatárok elválasztó és összekapcsoló szerepének a vizsgálata megkülönböztetett jelentőséggel bír ma már Kelet-KözépEurópa rendszerváltó országaiban is, miután az államhatárok elválasztó és összekapcsoló szerepének enyhülése a határon átívelỏ kapcsolatok kiszélesítésének a lehetőségeivel kecsegtet a Kárpát-medencében.

A határon átnyúló együttmüködések szerepe és jelentősége, az államhatárok funkcióinak az újraértelmezése az elmúlt évek során nemcsak a területi tudományok mủvelöi körében értékelődött fel, hanem az európai regionális politika formálói számára is, kủlönösen tekintettel a jelenben zajló európai integrációs folyamatokra. $\mathrm{Az}$ európai együttmüködést és egyesülést ugyanis a múltból öröklött történetiterületi-etnikai és egyéb problémák nehezítik Kelet-Közép-Európa politikai államhatárai mentén, miután a globalizációs és integrációs tendenciák jelentős akadályai azok a határszakaszok, amelyek mentén rendezetlen gazdasági-társadalmi-etnikai kérdések halmozódtak fel, s maradtak fenn mind a mai napig.

Szinte kézenfekvő tehát, hogy a kontinensen mind eröteljesebben kibontakozó euroatlanti integrációs folyamatokkal összhangban, a közelmúltban Európa-szerte látványosan felértékelödött az államhatárokon átívelö interregionális együttmúködések szerepe. Ennek mintegy természetes velejárójaként élénkült meg a figyelem a határok, a határmentiség és a határon átnyúló kapcsolatok kérdései iránt. A formálódó ún. határtudományok külföldi képviselői - néhány lépéssel megelözve a keleteurópai kutatókat - egyre szélesebb szakmai területeket vontak be vizsgálataikba, kutatási eredményeik pedig megtermékenyítöen hatottak a mind karakteresebben formálódó területi, $\mathrm{s}$ egyben a határrendészeti kérdésekkel foglalkozó tudományok hazai képviselöire. Korábban ilyen kérdésekkel más aspektusból inkább csak a történet- és a politikatudomány foglalkozott, az előző politikai rendszer ideológiai elvárásaihoz igazodva többnyire csak leíró jelleggel, kerülve a „kényes kérdésnek” minősülő határproblematikát. A változó körülmények, s nem utolsó sorban az Európai Unióhoz történő csatlakozás Magyarországon is a tudományos érdeklödés homlokterébe helyezték a határkutatást, mindenekelött a regionális, az ún. területi tudományok müvelői körében. 
A felfokozott érdeklődés kézzelfogható bizonyítéka Sallai János legújabb, viszonylag kis terjedelmü, de annál tartalmasabb könyve, amely szikár terjedelme ellenére is rendkívül adatgazdag, söt, ha tetszik komplex, ám lényegre törő összefoglalását jelenti az államhatárokkal, közelebbröl pedig a magyar államhatárokkal kapcsolatos legfontosabb elméleti, történeti és szorosabban vett szakmai határrendészeti kérdéseknek. A szerzö, mint határörtiszt, s mint a Rendörtiszti Föiskola Kutatásszervezési Osztályának vezetője és a föiskola tanára, valamint több más hazai felsőoktatási intézmény meghívott oktatója, már eddig több fontos munkával hívta fel magára a szükebb szakmai közönség és egyszersmind a tágabb érdeklödők figyelmét is. Főbb kutatási területeinek témáiból (Magyarország történelmi határai a térképtörténet tükrében; a magyar állam és etnikai határok kapcsolata; a Schengeni egyezmények elmélete és gyakorlata; az európai határőrség története stb.) számos írása és több könyve jelent meg.

A szerző jelenlegi kötete is joggal tekinthető a témában jelentős és hiánypótló munkának. A szerző ugyanis nemcsak a témakör határrendészeti szempontú feldolgozására, hanem a határtudományok elméleti, történeti és szakmai kérdései iránti mélyebb érdeklődés kielégítésére is törekedett. Miközben a szerzö átfogó képet igyekszik rajzolni az államhatárokról általában, és kiemelten a Kárpát-medence határairól, illetve azok történetéről, részletes áttekintést nyújt a magyar államhatárok történetéröl a középkortól egészen a legújabb időkig, söt kitekintéssel a jelenlegi EU-integrációs folyamatok, az ún. schengeni határőrizettel, a Schengeni Végrehajtási Egyezmény megvalósításával kapcsolatos elméleti és gyakorlati kérdésekre.

A hét fejezetbỏl álló könyv bevezetőjének tekinthető első két fejezet az államhatár általános elméleti, történeti kérdéseit vizsgálja, külön is hangsúlyozva az államhatár különböző funkcióit, az elválasztó, a szürő és összekötő jellegü szerepét, valamint a tudományos elemzésekben számon tartott egyéb funkciókat, a törvényességi, a fiskális és az ellenörzö, a katonai és az ideológiai funkciókat egyaránt.

A kötet dominánsan történeti részét alkotó harmadik és negyedik fejezetben a szerző kifejezetten az államhatárok magyarországi történetével foglalkozik, a korai középkortól, a gyepủrendszer kialakulásától, a későbbi történelmi korok és korszakok változásain, köztük a trianoni békeszerzödés után bekövetkezett helyzet részletes bemutatásán túl, majd az 1930-as évek végétöl napjainkig bekövetkezett terület- és határváltozások és azok következményeinek a részletes taglalásáig.

A következő nagy szerkezeti egységet alkotó ötödik és hatodik fejezet viszont már a középkori és a 19-20. századi határőrizet kifejezetten határrendészeti szempontú feldolgozását adja a határőrizetre vonatkozó mindenfajta fontos történeti, intézményi, szakmapolitikai, technikai változás és sokrétủ információ közreadásával.

Végül a könyv államhatárok jövỏjével foglalkozó nyolcadik fejezete mindenekelött a schengeni határőrizeti rend kérdéseinek, köztiik a Magyarország uniós tagságából fakadó jelenlegi helyzetnek és a várható következményeknek a bemutatását tekinti feladatának, ráirányítva a figyelmet azokra a körülményekre, amelyek Magyarország NATO és EU-tagságából adódóan aż államhatárok jellegének és szerepének az 
átértékelődését eredményezték a schengeni külső és belső határfunkciók függvényeként a különböző határviszonylatokat illetően. Ezzel összhangban a szerző joggal szögezi le a kötet zárómondatában a jelenlegi helyzet jellemzéseként, mintegy a továbbgondolkodás igényével, hogy „A határ összekötő szerepe a magyar-osztrák, magyar-szlovák és magyar-szlovén viszonylatokban, szürö szerepe a magyarromán és magyar-horvát viszonylatokban, míg elválasztó szerepe a magyar-ukrán és magyar-szerb viszonylatokban felerősödött."

A böséges és hasznos információt tartalmazó kötet jellegét tekintve akár a határtörténet, a határőrizet és határrendészet kérdései iránt érdeklödők kézikönyvének is tekinthetô, amit a gondolat- és ténygazdagság, valamint a feldolgozás komplex módszere alapoz meg. A szerző ugyanis munkája során egyaránt felhasználja a történelem, a földrajz, a nyelvészet, a néprajz és egyéb empirikus vizsgálatok eredményeit is, ráadásul mindezt rendkívül olvasmányos formában adva közre. A BM Oktatási Föigazgatósága által is támogatott, lebilincselỏen érdekes könyv a „célközönség", a szakmabeliek és rendészeti tanulmányokat folytatók mellett, a határkutatással foglalkozó regionális tudományok képviselőin túl, joggal tarthat számot tehát az olvasók szélesebb köreinek az érdeklődésére is. 
Tér és Társadalom 18. évf. 2004/3. 151-162. p.

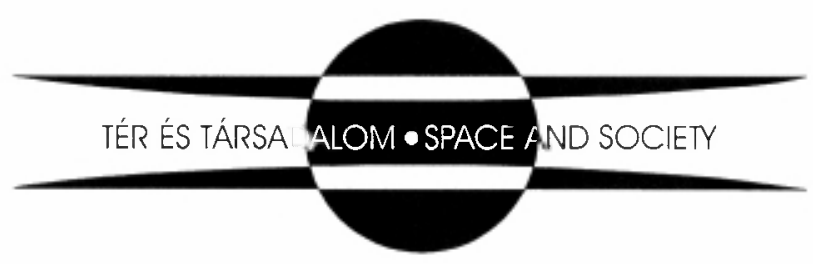

